\title{
EVALUATION OF A COMPOSITE SKIN SUBSTITUTE TO TREAT VENOUS STASIS ULCERS: A Pilot Study
}

\author{
Avaliação do uso de substituto de pele composto no tratamento de úlceras de estase venosa: \\ um estudo piloto
}

\author{
Paula Dadalti-Granja', Marco Aurélio Leiros², Bernardo M O Pascalleri ${ }^{3}$, Renata Brum Martucci', Radovan Borojevic ${ }^{3}$, \\ Talita Franco 5 , Marcia Ramos-e-Silva ${ }^{6}$, Christina Maeda Takyia ${ }^{3}$
}

\begin{abstract}
Introduction: Venous leg ulcers represent a therapeutic chal lenge, and they are associated to significant morbidity and cost. M any advances have been made to develop and apply biological skin substitutes, showing they can be beneficial for patients with burns, leg ulcers, and other skin lesions. A utologous cultivated keratinocytes have been demonstrated to be usef ul in leg ulcer treatment, but the lack of a dermal component may compromise their effects and the quality of the scar. Purpose: To evaluate a composite skin graft of human acellular dermis and autologous keratinocy te culture to treat leg ulcer. Methods: Two patients with four long-term chronic ulcers were treated with a composite skin graft of human acellular dermis and autologous kerati nocyte culture for a month in this pilot study. Results: The four ulcers had a surface reduction of $72.21 \%, 36.36 \%, 60.93 \%$, and $15.90 \%$ after one month of treatment. N o adverse tissue reactions were observed. Histology and immunohistochemistry showed that humam acellular dermis was free of donor's cells, and the composite skin substitute preserved the architecture of the normal skin, including the basement membrane components and stratified epidermis. Condusions: These preliminary observations suggest that such composite skin substitute could be an alternative to recalcitrant leg ulcers.
\end{abstract}

Keywords: Varicose U Icer; Extracellular M atrix; Skin, A rtificial; Tissue Culture Techniques; Cell Culture Techniques

\section{Institution}

1. Hospital Aristacho Pessoa, Corpo de Bombeiro Militar do Estado do Rio de Janeiro.

2. Hospital de Força Aérea do Galeão, Rio de Janeiro.

3. Embriology and Histology Department, Universidade Federal do Rio de Janeiro.

4. Cell Bank, Universidade Federal do Rio de Janeiro.

5. Sector of Plastic Surgery, HUCFF-UFRJ and School of Medicine, Universidade Federal do Rio de Janeiro.

6. Sector of Dermatology, HUCFF-UFRJ and School of Medicine, Universidade Federal do Rio de Janeiro.

\section{Address:}

\section{Paula Dadalti Granja}

Rua Almirante Calheiros da Graça, 57/303

CEP 20735190 - Rio de Janeiro - Brazil

Phone: $55213273-4131$

Fax: $\quad 55212547-7744$

E-mail: pauladadalti@terra.com.br

Recebido em: 22.02.2006

Aceito em: 30.03.2006

\section{INTRODUCTION}

L eg ulcers are quite frequent and associated to significant morbidity, high medical costs and major impact on the qual ity of life and work productivity. Venous stasis ulcers represent $70-90 \%$ of casesl, and their management represents a hard medical challenge. It is a consensus that compression is the main step to heal venous ulcers ${ }^{2,3}$, and, therefore, it is considered the gold standard therapy for such condition ${ }^{4}$. However, the healing rates can be as low as $22 \%$ after 12 week therapy and the 12-month recurrence rate, as high as $69 \% 5$. Over the last years, the development of biological skin substitutes brought new strategies to treat difficult-to-heal ulcers6. K eratinocy te sheet autografts have proved to be life saving to treat large third degree burns and have been successfully employed in managing chronic ulcers ${ }^{7}$. E pidermal equivalents prepared from autol ogous hair fol licle kerati nocytes applied on recurrent leg ulcers led to reepithelialization of $70 \%$ of the total wound surface after 8 weeks with a healing rate of $32 \% .{ }^{8} \mathrm{~A}$ Ithough their advantages are permanent and with rapid wound coverage, application onto large areas with material obtained from a small skin biopsy, and faster pain relief ${ }^{9}$, they present some inconveniences. They are fragile to manipulate, resulting in an unstable epithelium, giving rise to spontaneous blistering many months after grafting. A dditionally, they havean increased susceptibility to infections and contractures ${ }^{10}$. Histologically, the fragility of the grafted cultured epithelial autograft sheets may be related to the incomplete dermal- 
epidermal junction, giving rise to inadequate anchoring ${ }^{10}$. In order to improve the qual ity of the healed skin, some authors suggest the use of dermal replacement beneath these cultured epithelial grafts. ${ }^{11}$

Thus, a skin substitute constituted by a fibroblast-derived dermal replacement (Dermagraft ${ }^{\circledR}$ ) tested in patients with venous leg ulcers showed to improve the healing rate and the peri-ulcer skin perfusion ${ }^{12}$. A series of patients in a multicenter, prospective, randomized, controlled trial showed that the use of an allogeneic bilayered cultured skin equivalent (A pligraft ${ }^{\circledR}$ ) on hard-to-heal venous leg ulcers al lowed a complete wound closure in 6 months ${ }^{13}$. It seems that A pligraft is more effective and less expensive in healing venous leg ulcers than conventional therapy alone $\mathrm{e}^{14-17}$. Several types of simple composite substitutes have been developed, and one of them is acellular dermis covered with autologous keratinocytes ${ }^{18}$. A cellular human dermis is an allograft from which epidermal cellular components have been removed, with preservation of the dermal surface architecture and basement membrane complex. The process of removing the cellular elements, the most immunogenic components of an allograft skin, makes it an immunologic inert dermal tissue ${ }^{19}$.

Rennenkampff and colleagues examined the effects of an acellular dermal matrix on skin repair, and demonstrated that human keratinocytes persisted in all animals grafted with dermal matrix, compared to only $63.6 \%$ of animals with no dermal component ${ }^{11}$. They also showed a significantly reduced wound contraction in animals receiving dermal matrix.

Considering the therapeutic challenge represented by venous stasis ulcers, two patients with recalcitrant leg ulcers were treated with a composite skin substitute formed by human acellular dermis, and cultivated autologous keratinocytes, in order to establish the feasibility of the procedure as well as the tissue response to it.

\section{METHODS}

Patients - Two patients enrolled for the study were inpatients at the Clementino Fraga Filho University Hospital, who signed the informed consent as outlined for the project approved by the Hospital's Ethical Committee.

Case 1 - A 55 year old black man with two five-year old ulcers located at the mal eolar external and internal regions of the left leg, measuring $10.15 \mathrm{~cm}^{2}$ and $11.00 \mathrm{~cm}^{2}$, respectively. Clinically, there were signs of venous insufficiency, with preservation of the arterial pulses. D opplerfluxometry was compatible with venous insufficiency.

Case 2 - A 65 year old black man with three ten-year old ulcers. Patient had a history of traumatic ulcer (burn) and he had been submitted to a skin graft with no clinical improvement in the previous years. The ulcers were located on the anterior tibial area of the right leg, and they measured $10.65 \mathrm{~cm}^{2}, 0.70 \mathrm{~cm}^{2}$, and $6.35 \mathrm{~cm}^{2}$, respectively. The skin was covered by an atrophic scar, and there were signs of venous insufficiency. A rterial pulses were preserved and dopplerfluxometry was compatible with venous insufficiency.

In both patients, the autologous keratinocytes were obtained from a skin biopsy on the dorsum. Five and seven weeks later for case 1 and 2, respectively, the composite skin graft was applied over the ulcers. Before applying the skin substitute, the ulcers were cleaned with saline solution and superficially debridated after local anesthesia. The dressing used was A dapticT M (Johnson \& J ohnson).
The dressing was changed 5 days after the application and every 3 days for 8 weeks afterwards.

Keratinocyte cell culture - Normal skin autologous keratinocytes were obtained according to $\mathrm{G}$ reen and colleagues ${ }^{20}$. Biopsies were cut into fragments and submitted to mechanical dissociation of the epidermis from dermis followed by enzymatic dissociation with a $0.3 \%$ trypsin in calcium and magnesium-free saline solution. Cells were harvested by centrifugation and cocultured with 3-T3-J 2 mouse fibroblasts (obtained from the R io de Janeiro Cell Bank), pretreated with $15 \mu \mathrm{g} / \mathrm{ml}$ mitomycin- $C$ solution (B oehringer-M annheim, Indianapol is, IN ). They were maintained in keratinocyte culture medium consisting of a 1:1 mixture of Dulbecco's (DMEM, high glucose) and Ham's F12 media (both from GIBCO/BRL, Gaithersburg, M D, USA), supplemented with $10 \%$ fetal bovine serum (J R H Bioscience, L enexa, K S), adenine, $1.8 \times 10-4$ M (Sigma Chemical, St Louis, M O, USA), cholera toxin, 10-10 M (V ibrio Cholerae, type Inaba 569 B ; Calbiochem, L a Jolla, CA, USA), hydrocortisone, $0.4 \mu \mathrm{g} / \mathrm{ml}$ (Novo Nordisk, Princeton, NJ , USA), transferrin, $5 \mu \mathrm{g} / \mathrm{ml}$ (B oehringer-M annheim), triiodo-I-thyronine, 2x 10-9 M (Sigma), amphotericin B , $2.5 \mu \mathrm{g} / \mathrm{ml}$, and penicillin-streptomycin, 100l U/ml to $100 \mu \mathrm{g} / \mathrm{ml}$ (Boehringer$M$ annhei $\mathrm{m}$ ), and epidermal grow th factor, $10 \mu \mathrm{g} / \mathrm{ml}$ (Collaborative Biomedical Products, B edford, M A, USA). Cultures were incubated in a humidified $10 \% \mathrm{CO} 2$, at $37^{\circ} \mathrm{C}$.

Preparation of the acellular dermis - A cellular dermis was prepared from donor cadaver skin obtained from R io Transplante Skin B ank (hepatitis B - and HIV negative). A cellularization was obtained as to the modified protocol described by Ralston and colleagues ${ }^{21}$.

Fragments of skin were submitted to three rapid freeze-thaw cycles in liquid nitrogen to devitalize cells, washed three times in sterile PBS, and immersed in a series of increasing concentration of glycerol in phosphate saline buffers.

A fter being dried, acellular dermis was sterilized in ethylene oxide, rehydrated, and extensively washed in an $1 \mathrm{M} \mathrm{NaCl}$ solution. The epidermis was gently stripped from the dermis with a forceps, and the dermis was immersed in PBS with antibiotics solution (gentamycin at $100 \mu \mathrm{g} / \mathrm{ml}$, ciprofloxacin at $10 \mu \mathrm{g} / \mathrm{ml}$, amphotericin B at $2.5 \mu \mathrm{g} / \mathrm{ml}$, penicillin-streptomycin at $100 \mathrm{U} / \mathrm{ml}$ to $100 \mu \mathrm{g} / \mathrm{ml}$ ) at 40C for 4 weeks or more. B efore the use, the acellular dermis was washed three times in a saline solution to remove residual antibiotics.

Preparation of the composite skin grafts - Pieces of acellular dermis were placed into a 35-mm tissue culture dishes, with the papillary side up. Cultured keratinocytes $(0.5 \mathrm{ml}$ of $1.0 \times 106$ cells $/ \mathrm{ml})$ were seeded on top of the papillary surface of the acellular dermis and maintained 24 hours immersed in DM EM supplemented with 10\% fetal bovine serum. This "skin composite" was subsequently raised and maintained at the air-liquid interface for 1 week prior to grafting.

Clinical assessment - Two months of following patients up after the surgery each week. Photographs of ulcers were taken with a digital SONY Cybershot 2.1 megapixels camera, and the areas were measured by the software Image Tool for W indows (version 3.00), and a mean of three consecutive measurements was performed.

Immunostaining and histology - To monitor the structure of the composite skin substitute, a fragment was processed by routine histology techniques.

A n immunohistochemical study on paraffin sections characterized the presence of laminin and collagen type IV (DAKO, Carpinteria, CA, USA). 
A ntibodies were detected with LSAB + - HRP (DAKO), followed by diaminobenzidyne (DAB, DA KO), and hematoxylin counterstaining.

\section{RESULTS}

Composite skin substitutes' biopsy showed a stratified epidermis with presence of laminin and type IV collagen at the dermo-epidermal junction, as well as a complete acellularized dermis maintaining its original structure (Figure 1). To the application, grafts had approximately the same size of each ulcer. A fter the graft application, the integration of the composite skin substitute was visually recognizable, in both patients. The graft adhered to the underlying wound within 5 days. Patients referred pain reduction. They did not present any complain and no adverse or side effects related to the application were noticeable upon clinical examination.

Case 1 - 0 ne month after the application of the skin substitute, the ulcers' diameters reduced from $10.15 \mathrm{~cm}^{2}$ to $2.82 \mathrm{~cm}^{2}$ and from $11.00 \mathrm{~cm}^{2}$ to $7.00 \mathrm{~cm}^{2}$, representing a reduction rate of $72.21 \%$ and $36.36 \%$ respectively.

Case 2 - A fter 1 month of the composite skin substitute application, the area of the ulcers reduced from $10.65 \mathrm{~cm}^{2}$ to $4.16 \mathrm{~cm}^{2}$, and from $6.35 \mathrm{~cm}^{2}$ to $5.34 \mathrm{~cm}^{2}$. The reduction rate were repectively: $60.93 \%$ and $15.90 \%$. The third and smaller ulcer $\left(0.70 \mathrm{~cm}^{2}\right)$ completely healed. (Figure 2).

Figure 1: A) Human acellular dermis - Immunohistochemistry to collagen IV. Reactivity can be observed at the dermo-epidermal junction $\left(^{*}\right)$ and the vascular wall. Scale bar $1 \mu \mathrm{m}$. $100 x$

B) Composite skin substitute. Hematoxyllin Eosin X 100. It can be observed a stratified and differentiated epidermis with formation of a corneal layer ( $\downarrow$ ). Scale bar $1 \mu \mathrm{m}$. 100x

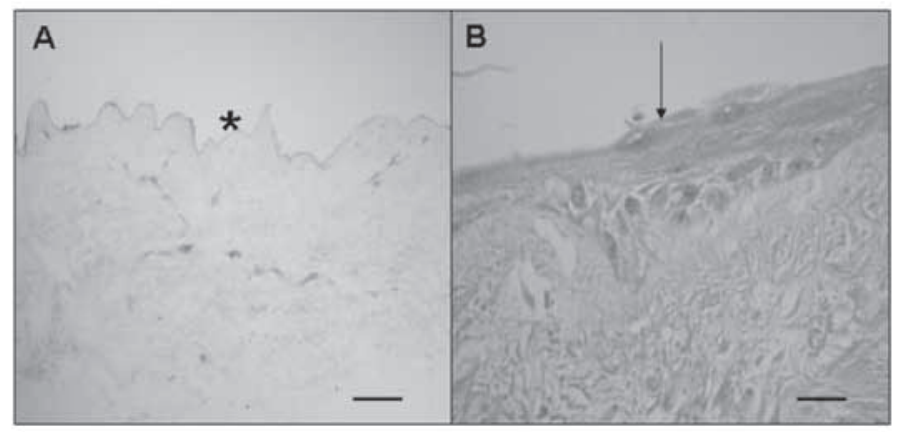

Figure 2: A) Case 2 patient, before applying the skin substitute. B) Same patient, 34 days after the application of the skin substitute, showing a size reduction of the ulcer.

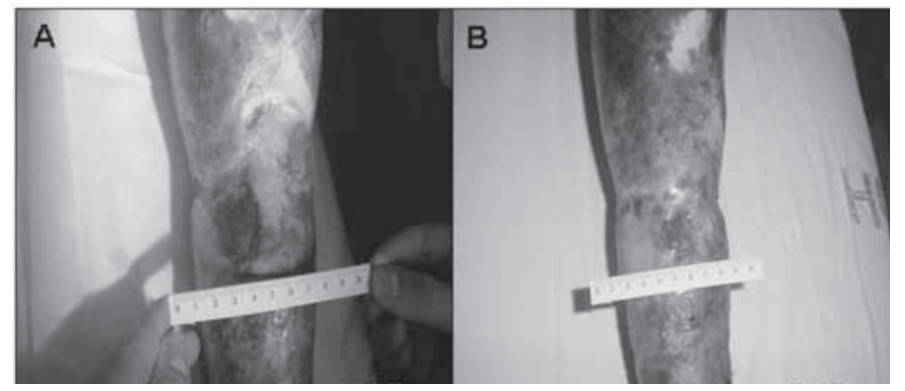

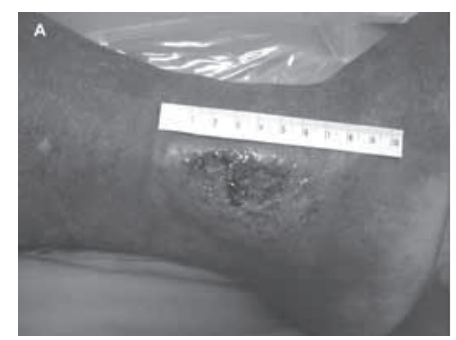

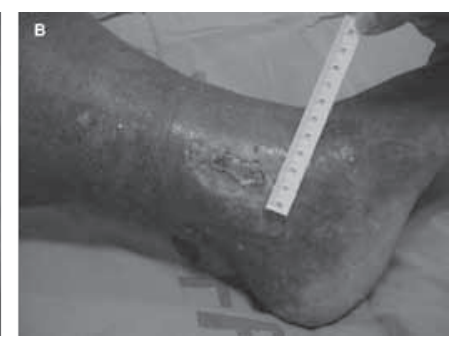

Figure 3 - A) Case 1 patient, before applying the skin substitute. B) Same patient, 43 days after the application of the skin substitute, showing a size reduction of the ulcer.

\section{DISCUSSION}

The established treatment protocols to leg ulcers, including debridement, compression therapy, and venous surgery optimized the wound healing environment but did not stimulate healing directly ${ }^{15}$. New advances in wound healing must provide an active stimulus to the wound.

Although split-thickness autograft remains an option, the pain at the donor site, healing delays, infection and hypertrophic scarring are a limitation for its current use ${ }^{22}$. The optimum characteristics of a skin substitute are: 1. rapid attachment to the wound allowing the revascularization; 2 . provide a barrier against fluid loss and infection; and 3. easy handling ${ }^{23}$. A dditionally, it should be nonantigenic, with minimal inflammatory or foreign body response and nontoxic ${ }^{9}$.

A lthough autologous culture keratinocytes may be useful to treat leg ulcers and to providea new epidermal surface, they are difficult to handle, generating an epidermis subject to physical stress, resulting in early graft loss, blistering and scarring ${ }^{18}$. The use of composite skin grafts here described disclosed no adverse events, made the manipulation of the graft easier, and increased the graft integration. Preservation of the basement membrane complex at the dermo-epidermal junction granted better mechanical properties of the healing skin. A lthough treated patients did not completely heal the ulcers in one month, their size had a significant reduction as well as morbidity. It is relevant to emphasize that those were long standing ulcers (5 and 10 years evolution), with larger than $5 \mathrm{~cm}^{2}$ area were considered refractory to traditional treatments. Prognostic indicators of venous ulcers demonstrated that in subjects with a greater than $5 \mathrm{~cm} 2$ only $40 \%$ healed baseline ulcer area with over 3 years duration, only $24 \%$ healed $^{6}$. A dditionally, patient 2 had a history of injury (burn) in the affected leg, and the skin bed was not optimum, surrounded by an atrophic skin, which could made the graft taking more difficult.

On the other hand, the encouraging results described with other composite skin substitute on leg ulcers (G raftskinT M ) ${ }^{24,25}$ were only attained with more than one application of graft. It is possible that successive applications of the present composite skin substitute may bring better results.

\section{CONCLUSION}

In this pilot study there were no side effect upon the application of the graft, and it was demonstrated the feasibility of this skin substitute to treat refractory leg ulcers. We are now engaged in a randomized study with a more expressive number of cases to estimate the accuracy of such composite skin substitute on leg ulcers compared to compression. 


\section{RESUMO}

Introdução: A s úlceras de estase venosa de perna representam um desafio terapêutico associado a significativa morbidade e custo. M uitos avanços têm sido realizados no desenvolvimento e aplicação de substitutos de pele biológicos, mostrando que estes podem ser benéficos para pacientes com queimaduras, úlceras e outras lesões de pele. Os queratinócitos autólogos cultivados têm demonstrado utilidade no tratamento de úlceras de perna, apesar da ausência de componentes dérmicos poder comprometer seus efeitos e a qualidade da cicatriz. Objetivo: Avaliar o uso de um substituto composto da derme humana acelularizada e queratinócitos autólogos cultivados no tratamento de úlceras de perna. Métodos: N este estudo piloto, dois pacientes com quatro úlceras crônicas de perna foram tratados com substituto de pele composto de derme humana acelularizada e queratinócitos autólogos cultivados durante um mês. Resultados: As quatro úlceras tiveram uma redução de tamanho de $72,21 \%, 36,36 \%, 60,93 \%$ e 15,90\% em um mês de tratamento. Nenhuma reação adversa foi observada. A histologia e a imuno-histoquímica mostraram que a derme acelular humana estava livre de células do doador, e o substituto composto preservava a arquitetura normal de pele, incluindo componentes de membrana basal e epiderme estratificada. Condusões: 0 s resultados preliminares sugerem que 0 substituto de pele composto pode ser uma alternativa para úlceras refratárias de perna.

\section{Descritores: Ú Icera Varicosa; M atriz Extracelular; Pele A rtificial; Técnicas de Cultura de Tecidos; Técnicas de Cultura de Células.}

\section{REFERENCES}

1. Miller F, Phillips TJ. Leg Ulcers. J Am Acad Dermatol. 2000;43:91-5.

2. Falanga V. Venous ulceration. J Dermatol Surg Oncol. 1993;19:764-71.

3. Phillips TJ, Dover JS. Leg ulcers. J Am Acad Dermatol. 1991;25:965-87.

4. Valencia IC, Falabella A, Kirsner RS, Eaglstein WH. Chronic venous insufficiency and venous leg ulceration. J Am Acad Dermatol. 2001;44(3):401-21.

5. Ghauri ASK, Taylor MC, Deacon JE, Whyman MR, Earnshaw JJ, Heather BP, Poskitt KR. Influence of a specialized leg ulcer service on management and outcome. Br J Surg. 2000;87:1048-56.

6. Phillips TJ, Machado F, Trout R, Porter J, Olin J, Falanga V and the venous ulcer study group. Prognostic indicators in venous ulcers. J Am Acad Dermatol. 2000;43:627-30.

7. Phillips TJ, Kehinde O, Green H, Gilchrest B. Treatment of skin ulcers with cultured epidermal allografts. J Am Acad Dermatol.1989;21:191-9.

8. Limat A, French LE, Blal L, Saurat JH, Hunziker T, Salomon D. Organotypic cultures of autologous hair follicle keratinocytes for the treatment of recurrent leg ulcers. J Am Acad Dermatol. 2003;48:207-14.

9. Ramos-e-Silva M, Castro MCR. New dressings, including tissue-engineered living skin. Clinics in Dermatol. 2002;20:715-23.

10. Jones L, Currie L, Martin R. A guide to biological skin substitutes. Br J Plastic Surg. 2002;55:185-93.

11. Rennekampff HO, Kiessig V, Griffey S, Greenleaf G, Hansbrough JF. Acellular human dermis promotes cultured keratinocyte engraftment. J Burn Care Rehabil.1997;18:535-44.

12. Omar AA, Mavor AID, Jones AM, Homer-Vanniasinkam S. Treatment of venous leg ulcers with dermagraft ${ }^{\circledR}$. Eur J Endovasc Surg. 2004;27:666-72.

13. Falanga V, Sabolinski M. A bilayered living skin construct (APLIGRAF) accelerates complete closure of hard-to-heal venous ulcers. Wound Repair Regen. 1999;7(4):201-7.

14. Schonfeld WH, Villa KF, Fastenau JM, Mazonson PD, Falanga V. An economic assessment of Apligraf ${ }^{\circledR}$ (Graftskin) for the treatment of hard-to-heal venous leg ulcers. Wound Rep Reg. 2000;8:251-257.
15. Weingarten MS. State-of-the-art treatment of chronic venous disease. Clinical Infectious Diseases. 2001;32:949-54.

16. Sibbald RG, Torrance GW, Walker V, Attard C, MacNeil P. Cost-effectiveness of Apligraf in the treatment of venous ulcers. Ostomy Wound Manage. 2001;47(8):36-46.

17. Fivenson D, Scherschun L. Clinical and economic impact of Apligraf ${ }^{\circledR}$ for the treatment of nonhealing venous leg ulcers. Int J Dermatol. 2003;42:960-5.

18. Medalie DA, Eming SA, Tompkins ML, Krueger GG, Morgan JR. Evaluation of human skin reconstituted from composite grafts of cultured keratinocytes and human acellular dermis transplanted to athymic mice. J Invest Dermatol. 1996;107:121-7.

19. Yukna RA, Turner DW, Robinson LJ. Variable antigenicity of liophliized allogenic and lyophilized xenogenic skin in guinea pigs. J Periodontal Res. 1977;12:197-203.

20. Green $\mathrm{H}$ et al. Growth of cultured humana epidermal cells into multiple epithelia suitable for grafting. Proc Natl Sci USA. 1979;765:5665-8.

21. Ralston, R.D., Layton, C., Dalley, A.J., et al. Keratinocytes contract human dermal extracellular matrix and reduce soluble fibronectin production by fibroblasts in a skin composite model. Br J Plast Surg. 1997;50:408-15.

22. Sheridan R, Choucair R, Donelan M, Lydon M, Petras L, Tompkins R. Acellular Allodermis in burn surgery: 1-year results of a pilot trial. J Burn Care Rehabil. 1998;19:528-30

23. Ralston DR, Layton C, Dalley AJ, Boyce SG, Freedlander E, Mac Neil S. The requirement for basement membrane antigens in the production of human epidermal/ dermal composites in vitro. Br J Dermatol. 1999;140:605-15.

24. Falanga V, Margolis D, Alvarez O, Auletta M, Maggiacomo F, Altman M, Jensen J, Sabolinski M, Hardin-Young J and The Human Skin Equivalent Investigators Group. Rapid healing of venous ulcers and lack of clinical rejection with an allogeneic cultured human skin equivalent. Arch Dermatol. 1998;134:293-300.

25. Brem H, Balledux J, Sukkarieh T, Carson P, Falanga V. Healing of venous ulcers of long duration with a bilayered skin substitute: results from a general surgery and dermatology department. Dermatol Surg. 2001;27:915-9. 